\title{
Cathartesaura anaerobica gen. et sp. nov., a new rebbachisaurid (Dinosauria, Sauropoda) from the Huincul Formation (Upper Cretaceous), Río Negro, Argentina
}

\author{
Pablo A. GALLINA ${ }^{1,3}$ \& Sebastián APESTEGUIA ${ }^{2,3}$ \\ ${ }^{1}$ Facultad de Ciencias Naturales y Museo- Universidad Nacional de La Plata, 122 y 60, 1900, La Plata, \\ Argentina. E-mail: paleopol@yahoo.com.ar. ${ }^{2}$ Museo Argentino de Ciencias Naturales "B. Rivadavia", \\ Av. Ángel Gallardo 470, (1405), Buenos Aires, Argentina. E-mail: paleoninja@yahoo.com.ar. ${ }^{3}$ Departamento \\ de Ciencias Naturales y Antropología (CEBBAD), Fundación de Historia Natural "Félix de Azara" - \\ Universidad Maimónides. V. Virasoro 732 (C1405BDB), Buenos Aires, Argentina.
}

\begin{abstract}
A new mid-sized sauropod from 'La Buitrera', Huincul Formation (Turonian-Coniacian), Río Negro Province, Cathartesaura anaerobica gen. et sp. nov. is described. It is known from an incomplete, but associated skeleton that includes diagnostic postcranial elements such as a posterior cervical, an anterior caudal, and a mid caudal vertebra, a left scapula, a left ilium and a right femur. Cathartesaura anaerobica gen. et sp. nov. exhibits several autapomorphies, such as a posterior cervical vertebra with an accessory lamina that arises from the mid length of the prezygodiapophysial lamina and reaches the centrum, a thin, wing-like transverse processes on the anterior caudal vertebrae mostly supported by a ventral bony bar that frames a deep triangular fossa, and each anterior caudal neural spine with the lateral laminae composed of the spinoprezygapophyseal lamina, the lateral spinopostzygapophyseal lamina and the spinodiapophyseal lamina. The new taxon is related to Rebbachisaurus and Limaysaurus because of the presence of several synapomorphies, which support its inclusion in a separate clade of basal Diplodocoidea, the Rebbachisauridae. Aspects of rebbachisaurid vertebral anatomy including musculature and pneumaticity are briefly commented upon. A cladistic analysis is presented in an attempt to partially resolve basal diplodocoid phylogenetic relationships.
\end{abstract}

Key words: Dinosauria, Sauropoda, Rebbachisauridae, Upper Cretaceous, Río Negro, Argentina.

The fossil record of the Cretaceous tetrapod fauna from Río Negro Province, North Patagonia, shows a high diversity of forms (Bonaparte, 1996; Apesteguía, 2002). A good example of this diversity is the locality known as 'La Buitrera', in which the upper member of the Candeleros Formation (Cenomanian-Turonian) as well as the basal member of the Huincul Formation (Turonian-Coniacian) crop out. This locality has provided rich faunas that include sphenodontians, snakes, araripesuchid crocodyliforms, theropod and sauropod dinosaurs, mammals, and ceratodontiform dipnoans (Apesteguía et al., 2001). A new sauropod from the basal Huincul Formation of 'La Buitrera' is described here. It belongs to a monophyletic group of basal Diplodocoidea, known as rebbachisaurids (Bonaparte, 1997).

The presence of a monophyletic subgroup of diplodocoids in the Cretaceous of Africa and South America was first recognized by Bonaparte (1996, 1997), who coined the family name Rebbachisauridae for this clade. That name was subsequently used by several authors (e.g. Wilson, 1999; Sereno et al., 1999; PeredaSuberbiola et al., 2001, 2003; Carvalho et al., 2003; Harris \& Dodson, 2004), without a formal diagnosis or valid definition until very recently (Salgado et al., 2004; Upchurch et al., 2004; Wilson, in press).

This group of moderately sized sauropods survived until the Upper Cretaceous, sharing environments with other sauropod lineages such as basal titanosaurs. They are mostly known from rather fragmentary remains, and many have not been described in detail yet. Most specimens remain unpublished or are only partially described (e.g. Nigersaurus taqueti), and only a few, such as Limaysaurus tessonei (Calvo \& Salgado, 1995) are nearly complete. Therefore, the in-group relationships of the Rebbachisauridae remain unclear.

Despite the dorsal vertebra described by Nopcsa (1902) from Neuquén Province and the materials from Morocco described by Lavocat (1954), most materials referred to Rebbachi- 
sauridae were only recognized as such in the last decade. A growing number of genera were assigned to this family, including Rayososaurus agrioensis Bonaparte 1996, from the Aptian of Neuquén, Argentina; Rebbachisaurus garasbae Lavocat 1954, from the Aptian-Albian of Morocco, Africa; Nigersaurus taqueti Sereno et al., 1999, from the Aptian-Albian of Niger, Africa; Rebbachisauridae indet. MPS-RV II PeredaSuberbiola et al. 2003, from the Lower Cretaceous of Spain; and Limaysaurus tessonei (Calvo \& Salgado, 1995) from the Cenomanian of Neuquén, Argentina.

The fossil record of the group was also expanded by additional undescribed materials from Cenomanian-Coniacian beds of Chubut Province, Central Patagonia (Lamanna et al., 2001). Although the higher-level systematic placement of the group is complex, most authors interpret them as basal diplodocoids (Calvo \& Salgado, 1995; Wilson \& Sereno, 1998; Wilson, 2002; Upchurch et al., 2004). On the other hand, the in-group relationships are still unclear. Furthermore, the still poor knowledge of their anatomy invokes the risk of including other species that were part of the wide radiation experienced by basal diplocoids between the Late Jurassic and Early Cretaceous among Rebbachisauridae, thus rendering them a taxonomic 'waste-basket'. A cladistic analysis is presented here as an attempt to partially resolve their phylogenetic relationships.

Institutional abbrevations. MPCA- Museo Provincial Carlos Ameghino, Cipolletti, Río Negro, Argentina. MCF- Museo Carmen Funes, Plaza Huincul, Neuquén, Argentina. MPS-RV-II: Museo de Dinosaurios - Paleontología, Salas de los Infantes, Burgos, Spain. Pv-MOZ: Museo "Profesor Dr. Juan Olsacher", Zapala, Neuquén, Argentina.

\section{SYSTEMATIC PALEONTOLOGY}

Saurischia Seeley, 1888

Sauropodomorpha Huene, 1932

Sauropoda Marsh, 1878

Diplodocoidea Upchurch, 1995

Rebbachisauridae Bonaparte, 1997

\section{Cathartesaura gen. nov.}

Type species. Cathartesaura anaerobica sp. nov.

Diagnosis. Mid-sized sauropod dinosaur characterized by the following derived features: posterior cervical vertebra with an accessory lamina

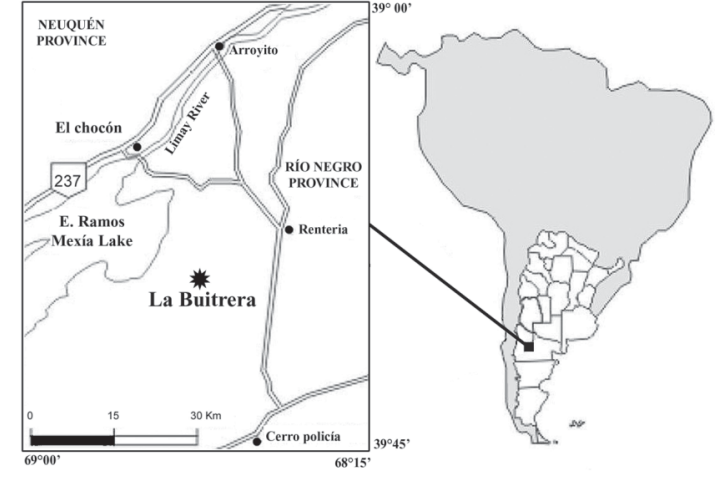

Fig. 1. Map showing the "La Buitrera" locality, Río Negro Province, Northern Patagonia.

that arises from the middle of the prezygodiapophysial lamina and reaches the centrum; thin wing-like transverse processes of anterior caudal mostly supported by the ventral bar forming a deep triangular fossa, also framed by the prezygodiapophyseal and centroprezygapophyseal laminae; anterior caudal neural spine with the lateral lamina composed of the spinoprezygapophyseal lamina, the lateral spinopostzygapophyseal lamina and the spinodiapophyseal lamina.

Etymology. Cathartes, for the extant vultur genera abundant in the quarry area; saura (Greek), fem. lizard, reptile. Additionally, it implies the combination of the generic and specifical names of those vultures (Cathartes aura Linnaeus, 1758).

\section{Cathartesaura anaerobica, nov. sp.}

Diagnosis. Same as for genus.

Etymology. Fem. for ANAEROBICOS S. A., an Argentine company of adhesives that provided fieldwork and lab support in the extraction and protection of the fossil materials.

Holotype. MPCA- 232, consisting of the following associated material from one quarry and presumably from a single specimen: a posterior cervical vertebra, a dorsal vertebra, an anterior caudal, a mid caudal vertebra, left scapula, a left? ilium, and a right femur. A dorsal vertebra, a humerus and one metatarsal were also collected, but they are poorly preserved.

Horizon and locality. Sandy to pelitic levels of the lower section of the Huincul Formation, regarded as Cenomanian (Leanza \& Hugo, 2001) to Coniacian (Corbella et al., 2004) at 'La Buitrera', 80 km SW of Cipolletti, Río Negro Province, Argentina (Fig. 1). 


\section{COMPARATIVE DESCRIPTION}

Posterior cervical vertebra (Fig. 2A, B). A complete posterior cervical vertebra (possibly the eighth or ninth) was recovered. This vertebra is twice as tall as it is long. The neural arch makes up approximately $2 / 3$ of the total height. The centrum is opisthocoelous, elongate and dorsoventrally compressed, its length being three times its height. The cervical system of pneumatic cavities consists of two independent and successive foramina that connect to their respective internal camerae (Wedel et al., 2000). They are oval in shape with an oblique long axis, and are located on the lateral wall of the centrum occupying at least $3 / 4$ of its length. Both "pleurocoels" (foramina and camerae) are separated by a thin oblique septum ("pleurocentral" lamina sensu Calvo \& Salgado, 1995) that runs parallel to the posterior centrodiapophyseal lamina.

The first camera is slightly smaller than the second and is placed above the parapophysis and rostral to the level of the diapophysis. In contrast to the second camera, the first camera is only a shallow concavity with no internal divisions. The second and larger camera is more complex, excavating the interior of the centrum up to its posterior end. Actually, this camera is separated from the concave surface of the posterior articulation of the centrum by a thin lamina of bone (Fig. 2B).

The neural canal is large with a horizontal floor, and is developed as a wide arch that occupies most of the neural arch base. In lateral view, there are four main laminae that converge on the diapophysis around the middle of the vertebral length as in Haplocanthosaurus and diplodocoids. A deep, posterior, and triangular fossa is framed by the postzygodiapophysial and posterior centrodiapophysial laminae. The centropostzygapophysial lamina, which narrows upwards, closes the triangle posteriorly. A similar, but shallower and inverse triangle is framed by the prezygodiapophysial and anterior centrodiapophysial laminae.

Two weaker accessory laminae are visible on the lateral aspect of the neural arch. The first connects the postzygodiapophysial and spinoprezygapophysial laminae at the middle of their spans (AL1). Originally proposed as an autapomorphy for Limaysaurus tessonei, it certainly represents a synapomorphy of a more inclusive group (Gallina et al., 2002). The second accessory lamina arises from the mid-length of the prezygodiapophysial lamina and reaches the centrum (AL2). It is here considered as an autapomorphy of Cathartesaura. In posterior view,

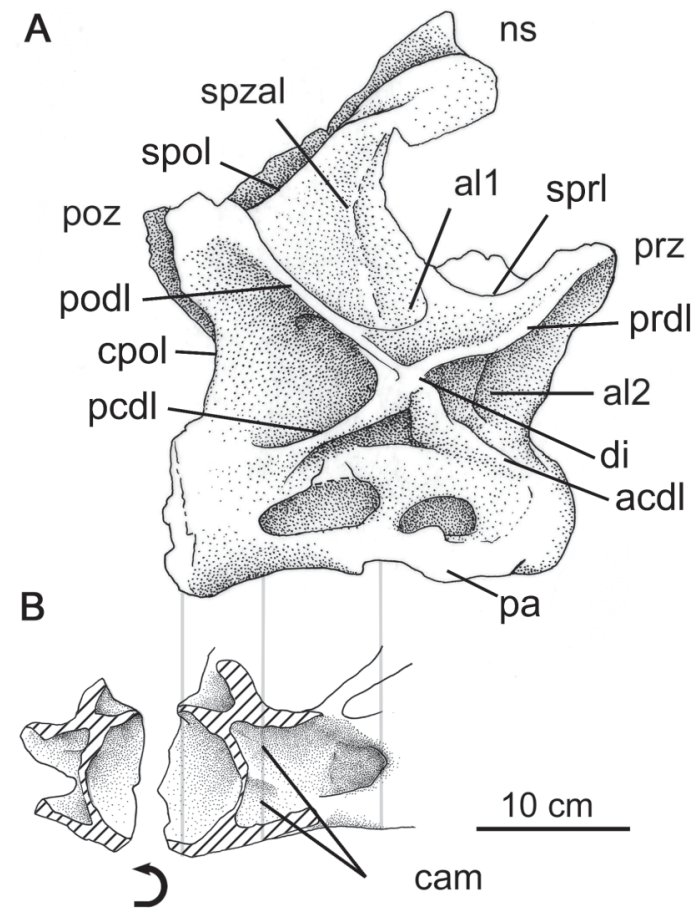

Fig. 2. Cathartesaura anaerobica gen. et sp. nov. Posterior cervical vertebra. A, right lateral view; $\mathrm{B}$, detail of the centrum showing internal cavities. Abbreviations: acdl, anterior centrodiapophyseal lamina; al1, accesory lamina 1; al2, accesory lamina 2; cam, camerae; cpol, centropostzygapophyseal lamina; di, diapophysis; ns, neural spine; pa, parapophysis; pcdl, posterior centrodiapophyseal lamina; podl, postzygodiapophyseal lamina; poz, postzygapophysis; prdl, prezy-godiapophyseal lamina; prz, prezygapophysis; spol, spinopostzygapophyseal lamina; sprl, spinoprezygapophyseal lamina; spzal, suprapostzygapophyseal accesory lamina.

two weak laminae run parallel to the spinopostzygapophysial laminae. Their presence in other rebbachisaurids is unknown.

The neural spine is square in cross-section at its base, and becomes a thin lamina at the summit. The spine is obliquely inclined and oriented forward, its origin being in the posterior half of the centrum. It is buttressed anteriorly by the spinoprezygapophysial laminae and posteriorly by the spinopostzygapophysial laminae. There is also a lateral column-like, robust lamina that reaches two cm in width (probably the SPZAL of Calvo \& Salgado, 1995).

Anatomical comments. Most researchers (e.g. McIntosh, 1990) consider that the system of cavi- 
ties in the sauropod axial skeleton is profoundly associated with the lightening of the skeleton. Furthermore, Wedel et al. (2000) and Wedel (2003a, b) proposed that the cavities are the result of pneumatic invasion by the pulmonary air sac system. On the other hand, Bonaparte (1999) suggested that the cavities and laminae in presacral vertebrae mostly served as attachment for hyposomatic musculature which, for Wedel \& Sanders (2002), were developed in other anatomical structures.

In Cathartesaura, the development of tall, distally widened neural spines, as well as strong spinopostzygapophyseal and accesory laminae on their posterior sides, indicates a strong development of the epaxial musculature, most probably the $M$. longus colli dorsalis, $\mathrm{Mm}$. intercristales, and $\mathrm{Mm}$. interspinales of birds (see Wedel \& Sander, 2002). This important development of dorsal structures also avoided an excessive flexure of the neck. On the other hand, the lack of the ansa costotransversia (bony bridge formed by cervical rib + diapophysis + parapophysis) due to taphonomy, precludes an analysis of the relative development of the hypaxial musculature.

The pneumaticity of the cervical vertebrae of Cathartesaura anaerobica is well-developed and provides an important source of anatomical information. Based on the morphological types of Wedel et al. (2000), Cathartesaura bears camerate vertebrae, with lateral foramina that open into a large central camera that bifurcates into smaller camerae as in Limaysaurus and Diplodocus.

Anterior caudal vertebra (Fig. 3A, B, C). One complete anterior caudal vertebra has been recovered, probably the second or third of the caudal series. This vertebra is more than three times taller than long. The centrum is amphyplatian and subcircular in shape, with a length / height ratio of about 1.5 . There is no sign of pneumatic cavities in the centrum.

The tall neural arch is at least twice the centrum height (a synapomorphy of Diplodocoidea, reverted in Diplodocidae) as in Haplocanthosaurus, Losillasaurus, and the indeterminate rebbachisaurid MPS-RV II. In the latter, as is the case in the Titanosauriformes (Salgado et al., 1997), the neural arch is located toward the anterior half of the centrum. Two deep fossae are located laterally on the most anterior part of the base of the neural arch. The neural canal is semicircular and well defined. The development of the zygapophyses shows a significant reduction of both prezygapophysis and postzygapophysis, a condition also present in Dicraeosaurus, Amazonsaurus and the isolated rebbachisaurid neural arch MCF-PVPH-633. Moreover, the re- duced prezygapophyses fit in narrow slits where each postzygapophyses are dorsomedially located. As in most diplodocoids, the transverse processes are wing-like, but in Cathartesaura they are thin laminae of bone mostly supported by the ventral bar. They border a deep triangular fossa, also bounded by the diapoprezygapophyseal and centroprezygapophyseal laminae, which occupies the entire lateral face of the neural arch, and is here considered an autapomorphy of Cathartesaura.

The neural spine is S-shaped in lateral view as in Rebbachisauridae indet. MPS-RV-II, and it is positioned at the most anterior part of the neural arch, its base being oriented backwards and its summit forward. It is composed of the intersection of four conspicuous laminae, one each at the anterior, posterior and lateral sides. These laminae increase in thickness distally to end in bulky borders. Both prespinal and postspinal laminae reach the base of the neural arch.

The lateral lamina arises from the juncture of three laminae (Fig. 3E): the spinoprezygapophyseal (sprl), the lateral spinopostzygapophyseal (lat. spol.), and the spinodiapophyseal laminae (spdl). This multiple juncture is unique for Cathartesaura, whereas in other diplodocoids the lateral lamina involves the fusion of the spinodiapophyseal and lateral spinopostzygapophyseal laminae (e.g., Apatosaurus louisae, Limaysaurus sp. Pv-6722-MOZ), or the spinoprezygapophyseal, and spinodiapophyseal laminae (e.g., Amazonsaurus, Dicraeosaurus hansemanni, MCF-PVPH-633). The more conspicuous component to form this lateral lamina in Amazonsaurus, Dicraeosaurus hansemanni, and MCF-PVPH-633 is the anterior one, arising from the prezygapophysis. Conversely, in Apatosaurus and Cathartesaura it is the posterior one. However, whereas the former originates from a single lamina (lat. spol.), the latter includes the fusion of two laminae (lat. spol. + spdl).

Mid caudal vertebra (Fig. 3F). One mid-caudal vertebra has been recovered. The centrum is amphyplatian and elongate. The lateral sides of the centrum are concave and the ventral surface is flat. In anterior view the centrum is triangular (wide base) as in Limaysaurus and Amazonsaurus.

The neural arch makes up approximately half the total height and is located at the middle of the centrum. Neither the prezygapophysis nor the postzygapophysis exceed the centrum length, and the prezygapophysis is oriented horizontally. Transverse processes are not developed. The neural spine is transversely compressed and directed posteriorly. 


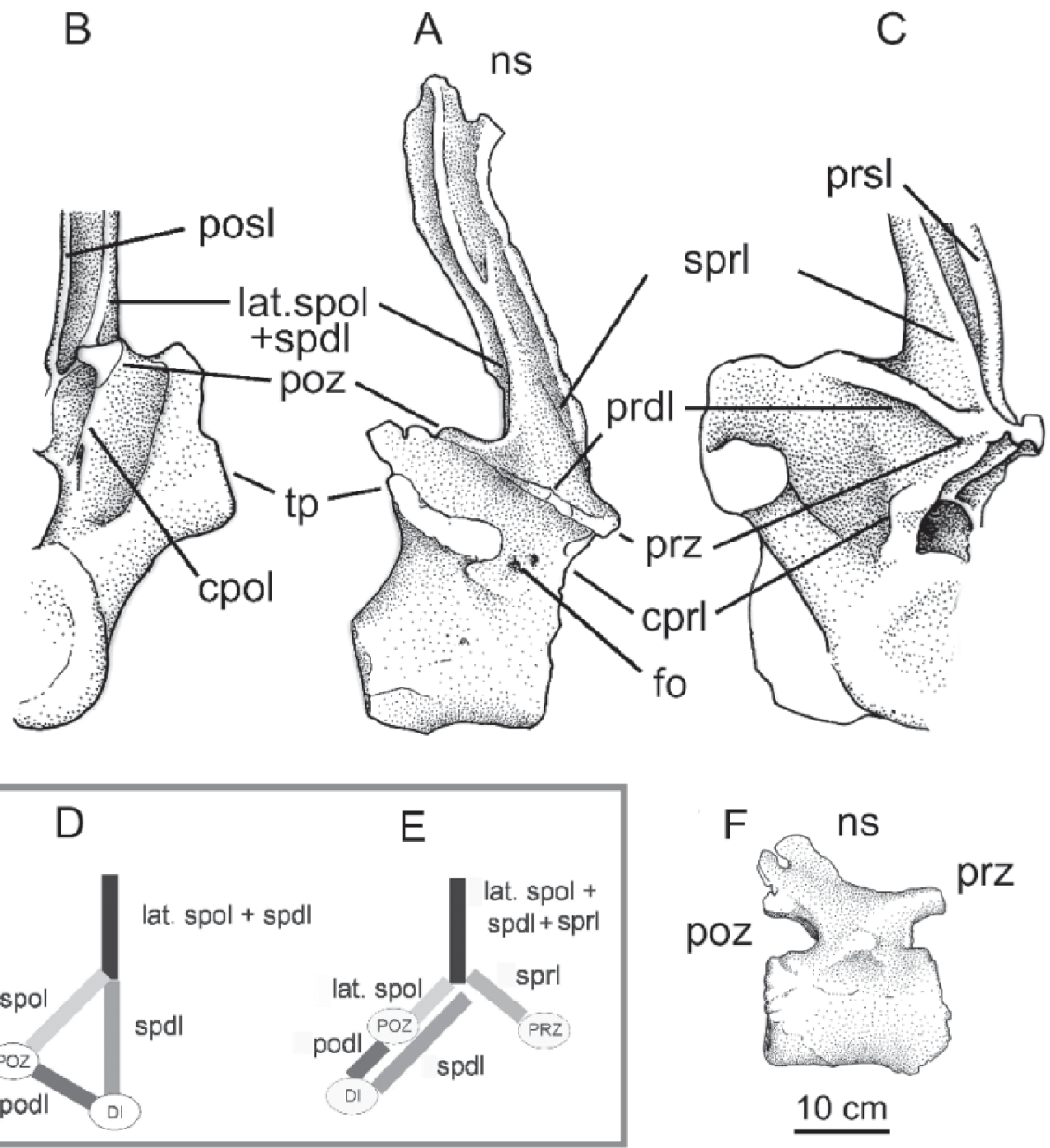

Fig. 3. Cathartesaura anaerobica gen. et sp. nov. Caudal vertebrae. Anterior caudal vertebra in $\mathrm{A}$, right lateral view, $\mathrm{B}$, right posterior detail and $\mathrm{C}$, right anterior detail. Main components of the lateral lamina in anterior caudal neural spine from D, Apatosaurus louisae, and E, Cathartesaura anaerobica. F, mid-caudal vertebra in right lateral view. Abbreviations: cpol, centropostzygapophyseal lamina; cprl, centroprezigapophyseal lamina; di, diapophysis; fo, fossa; lat.spol, lateral spinopostzygapophyseal lamina; sprl, spinoprezygapophyseal lamina; ns, neural spine; posl, postspinal lamina; prsl, prespinal lamina; prz, prezygapophysis; poz, postzygapophysis; prdl, prezygodiapophyseal lamina; spdl, spinodiapophiseal lamina; tp, transverse processes.

Scapula (Fig. 4A). A left scapula was collected, but its dorsal edge is poorly preserved. The bone, $68 \mathrm{~cm}$ in length, is considerably expanded distally, and the minimal width of the post-acromial region reaches only $16 \mathrm{~cm}$. Despite the poor preservation, it can be said that it was racquetshaped as in other rebbachisaurids. The hooklike acromial process is well defined, as in Rayososaurus.

In ventral view the shaft exhibits a strong curvature, developed medially with respect to the level of the acromion. The glenoid border forms a low angle with respect to the direction of the shaft. The scapula-coracoid contact seems to be rounded.

Ilium. The left ilium was recovered, but remains mostly unprepared. The iliac blade is slightly concave in lateral view, and the caudal part is curved outwards. The dorsal edge of the ilium is convex. The postacetabular process and the ischial peduncle are poorly preserved. Although incomplete, the pubic peduncle is devel- 

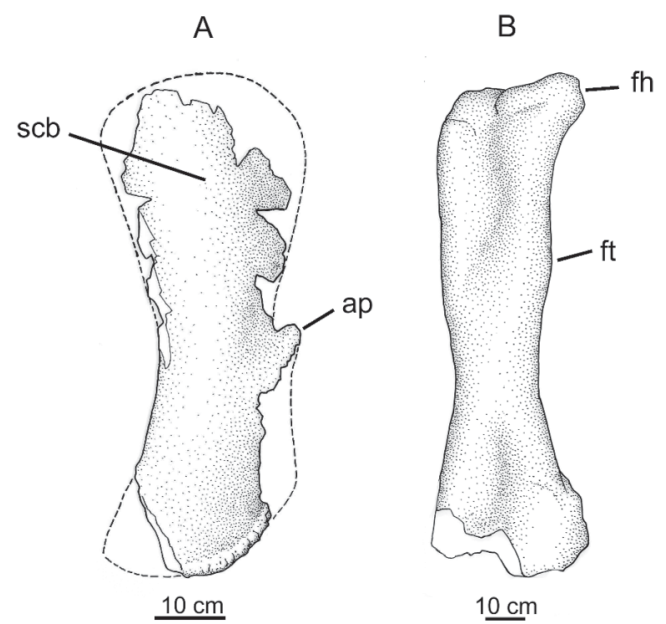

Fig. 4. Cathartesaura anaerobica gen. et sp. nov. Pectoral girdle and hind limb. A, left scapula in lateral view and $\mathrm{B}$, right femur in anterior view. Abbreviations: ap, acromial processes; fh, femoral head; ft, fourth trochanter; scb, scapular blade.

oped perpendicular to the blade. This kind of acetabular orientation is also present in titanosauriforms and Amanzonsaurus maranhensis.

Femur (Fig. 4B). A right femur was recovered. This bone is $1,38 \mathrm{~m}$ long, similar in size to that of Limaysaurus tessonei ( $1,41 \mathrm{~m}$ long). This femur is robust and anteroposteriorly compressed. The distal end is poorly preserved so the distal condyles are not observable. In posterior view, the fourth trochanter is located on the upper mid-section and is developed as a lateral short bulge in anterior view; this condition is also observable in Camarasaurus grandis, Haplocanthosaurus priscus and Dicraeosaurus hansemanni.

The lateral margin of the femur is straight and a lateral bulge (as present in titanosauriforms, see Salgado et al., 1997) is not developed.

\section{PHYLOGENETIC RELATIONSHIPS OF CATHARTESAURA}

A cladistic analysis based on 77 characters in 19 taxa (see Appendix) was carried out in order to clarify the phylogenetic relationships of Cathartesaura within Sauropoda. The designated outgroup in the analysis was Patagosaurus fariasi (Bonaparte, 1979), whereas the ingroup consisted of Losillasaurus giganteus (Casanovas et al., 2001); Haplocanthosaurus priscus (Hatcher, 1903); H. delfsi (McIntosh \& Williams,
1988); Camarasaurus grandis (Cope, 1877); Amargasaurus cazaui (Salgado \& Bonaparte, 1991); Dicraeosaurus hansemannii (Janensch, 1914); D. sattleri (Janensch, 1914); Suuwassea emilieae (Harris \& Dodson, 2004); Apatosaurus louisae (Marsh, 1877); Barosaurus lentus (Marsh, 1890); Diplodocus carnegii (Hatcher, 1901); Limaysaurus tessonei; Limaysaurus sp. Pv-67/67MOZ (Salgado et al., 2004); Nigersaurus taqueti; Rebbachisaurus garasbae; Rayososaurus agrioensis; Rebbachisauridae indet. MPS-RV II; and Cathartesaura anaerobica gen. et sp. nov. (this paper).

Amazonsaurus maranhensis (Carvalho et al., 2003), Histriasaurus boscariollii (Dalla Vecchia, 1998) and a caudal neural arch MCF-PVPH-633 were considered for comparisons, but were not included in the cladistic analysis. Rayososaurus and Limaysaurus are considered as separate genera (contra Calvo \& Salgado, 1996; Wilson \& Sereno, 1998). The only bones in common (scapula and femur) are clearly different (Bonaparte, 1997) in morphology, and the taxa are temporally separated. These distinctions are reflected in the relative position of both taxa in the results of our phylogenetic analysis.

Camarasaurus was included as representative of certain macronarians to avoid the phylogenetic problems caused by the recognised convergences between derived macronarians (i.e., titanosaurs) and diplodocoids (Upchurch, 1999; Apesteguía, 2004).

The data matrix was run using the program NONA, version 2.0 (Goloboff, 1993), and the character polarity was determined by comparison with the outgroup. Multi-state characters were treated as unordered. Five most parsimonious cladograms were obtained, with relatively high indices (140 steps, consistency index: 0.66 , retention index: 0.73) (Fig. 5A). The basal nodes 1, 2, 3 , 4, and 5 (Neosauropoda, Macronaria, Diplodocoidea, Rebbachisauridae and Flagellicaudata) and the more derived taxa (nodes 6 and 7, Dicraeosauridae and Diplodocidae) are relatively well supported. In contrast, the other nodes are weaker due to missing data.

The cladogram shows some similarities with previous studies (Wilson, 2002; Harris \& Dodson, 2004), although it also shows some novel groups, which add to our knowledge of rebbachisaurid evolution and the phylogenetic position of controversial taxa (i.e. Losillasaurus, Haplocanthosaurus, Suuwassea). The strict consensus cladogram shows an unresolved polytomy at the base of Rebbachisauridae with the exception of a node shared by L. tessonei and Nigersaurus taqueti (Fig. 5C). Rebbachisauridae is here sup- 


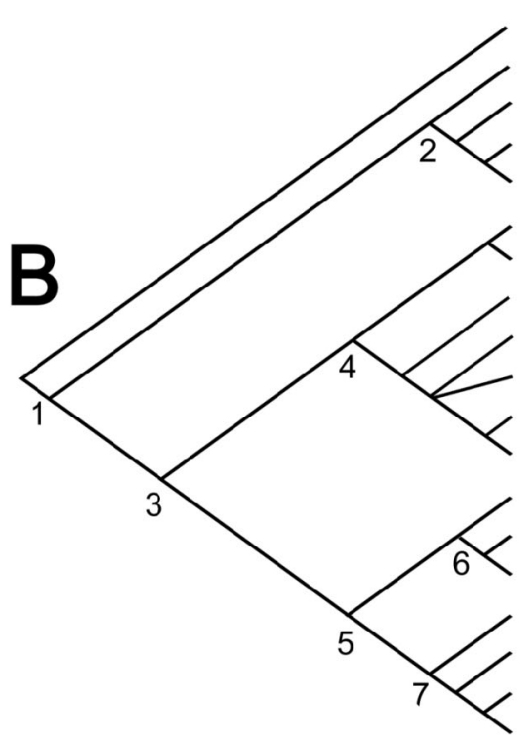

Patagosaurus Losillasaurus H. priscus Camarasaurus H. delfsi L. tessonei Nigersaurus Rebbachisaurus Rayososaurus Cathartesaura PV 6718/67 MOZ MPS-RV II Amargasaurus D. hansemanii D. sattleri Suuwassea Apatosaurus Barosaurus Diplodocus

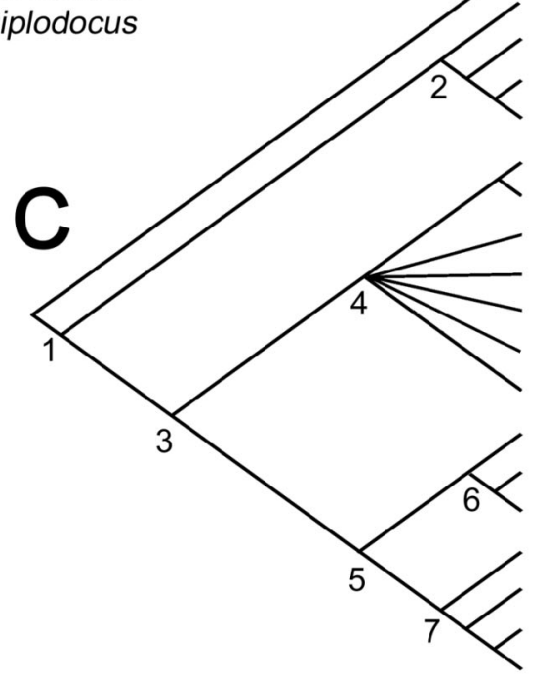

Patagosaurus Losillasaurus H. priscus Camarasaurus H. delfsi L. tessonei Nigersaurus Rebbachisaurus Rayososaurus Cathartesaura PV 6718/67 MOZ MPS-RV II Amargasaurus D. hansemanii D. sattleri Suuwassea Apatosaurus Barosaurus Diplodocus
Patagosaurus Losillasaurus H. priscus Camarasaurus H. delfsi L. tessonei Nigersaurus Rebbachisaurus Rayososaurus Cathartesaura PV 6718/67 MOZ MPS-RV II Amargasaurus D. hansemanii D. sattleri Suuwassea Apatosaurus Barosaurus Diplodocus

Fig. 5. Phylogenetic relationships of Cathartesaura anaerobica gen. et sp. nov. within Sauropoda. A, One of the five most parsimonious tree; B, $50 \%$ majority-rule consensus tree and C, strict consensus tree. Nodes: 1-Neosauropoda, 2-Macronaria, 3-Diplodocoidea, 4-Rebbachisauridae, 5-Flagellicaudata, 6-Dicraeosauridae and 7-Diplodocidae. 
ported by six unambiguous synapomorphies: Presence of a well developed accessory lateral lamina connecting postzygodiapophyseal and spinoprezygapophyseal laminae in posterior cervical vertebrae (25.2); presence of anterior caudal neural spines with the lateral border initially flat but ending in a distally thickened bulky summit (53.1); wide-based, triangular mid-caudal centra (60.2); racquet-shaped scapular blade (63.2); and presence of a hook-like acromion process (69.1).

Although the strict consensus of our analysis retrieves Limaysaurus tessonei and Nigersaurus taqueti as a monophyletic subclade, there is no strong support for it.

In our analysis, Diplodocoidea is supported by twenty unambiguous synapomorphies. The recently described Suuwasea, considered as a basal diplodocoid, is here considered a basal diplodocid. Losillasaurus, which varies widely in previous analyses from being a basal neosauropod (Casanovas et al., 2001) to a basal eusauropod (Harris \& Dodson, 2004), is here considered a basal macronarian or closely related to them. Additionally, Haplocanthosaurus is again found to be a paraphyletic taxon (Calvo \& Salgado, 1995), but more closely related to basal macronarians (as in Wilson \& Sereno, 1998; Casanovas et al., 2001) than to diplodocoids.

\section{DISCUSSION AND CONCLUSIONS}

Diplodocoids were globally distributed sauropods that evolved some lineages restricted to northern landmasses (diplodocids) and southern landmasses (dicraeosaurids). Their basal forms, however, show a more ambiguous distribution.

Although several Early Cretaceous dinosaurs (e.g. basal neosauropods; basal neotetanurans; basal neoceratosaurians; eurypodans and basal iguanodontians) show a rather worldwide distribution since Late Pangean times, the incipient Laurasian - Gondwanan provincialism initiated during the Late Jurassic (Bonaparte, 1979; Rauhut, 2002) was certainly more evident by Early Cretaceous times.

The Rebbachisauridae, abundant during the Early Cretaceous, show a preferentially Gondwanan distribution. However, recent findings in Barremian to Aptian rocks of Spain (Pereda Suberbiola et al., 2003) extend their distribution northwards. Despite this undoubted presence on a northern landmass, the paleogeographical relationships between Iberia and Gondwana remain too complicated (Scotese et al., 1999; Vrielynch \& Bouysse, 2003; Scotese, 2004) to depict a paleobiogeographical scenario for rebbachisaurids. Furthermore, their absence in the Wealden deposits and all North American units supports a mostly southern distribution.

The Uppermost Cretaceous strata of the Gondwanan landmasses are marked by the dominance of abelisaurian theropods and titanosaurian sauropods. However, their faunal make-up is more complicated in the earlier stages of the Upper Cretaceous.

Southern Neuquén basin is, perhaps, the richest fossiliferous area for Upper Cretaceous continental tetrapods. Its faunal content was recently characterized in detail by Leanza et al. (2004), and separated into four recognizable faunal assemblages, in concordance with their stratigraphic distribution: Limayan, Neuquenian, Coloradoan and Allenian assemblages.

The occurrence of rebbachisaurids in the early Upper Cretaceous of Patagonia (Limayan assemblage) is noteworthy, because they represent the only diplodocoids worldwide recorded during this interval (Salgado et al., 1991; Calvo \& Salgado, 1995; Calvo \& Salgado, 1998; Calvo, 1999; Apesteguía et al., 2001; Gallina et al., 2002). Furthermore, their absence in rocks younger than the "Mid" Cretaceous suggested to several authors the presence of an extinction event that involved these diplodocoids (Salgado, 2001; Apesteguía, 2002; Leanza et al., 2004). Salgado (2001) correlated this event with that responsible for the complete extinction of the Laurasian sauropods, and the diversification of the narrowcrowned titanosaurs, which Gallina et al. (2002) related directly to the rise of saltasaurine titanosaurs. Additionally, Apesteguía (2002) correlated the diplodocoid extinction to that of carcharodontosaurid theropods, the rise of coelurosaurian and abelisaurian theropods, and the change in dominance from araripesuchid to notosuchid mesoeucrocodylians, and from chelid to podocnemidoid turtles. This occurred during his Gondwanan Evolutionary Stage, between the Early Gondwanan and the South American Domain for tetrapod faunas.

The youngest record of rebbachisaurids is considered by most authors as those from the Huincul Formation (Neuquén basin) and the Bajo Barreal Formation (San Jorge basin). Although the square-shaped mandible of the Coloradoan titanosaur Antarctosaurus wichmannianus (Huene, 1929) suggested some authors to consider diplodocoids as present in Campanian times (Jacobs et al. 1993; Upchurch 1999; Wilson \& Sereno, 1998), recent findings (Apesteguía, 2004) demonstrated that titanosaurs also had square jaws. Therefore, there is no compelling evidence 
to support the presence of rebbachisaurids after Coniacian times. This is apparently true for Neuquén, San Jorge and Austral basins, from North, Central and Southern Patagonia respectively.

Late Cretaceous sauropod lineages are considered convergent (Salgado \& Calvo, 1997; Wilson, 2002) in their 'horse-like' skulls, restriction of the cylindrical, narrow-crowned teeth to the anterior part of the snout, comb-like dentition (Coria \& Chiappe, 2001), square mandibular symphyses, and nostrils retracted to the top of the head. Both main lineages (titanosaurs and rebbachisaurids) are convergent in the loss of accessory articulations (i.e. hyposphenehypantrum complex). This trait would have provided a higher mobility and greater flexibility to the vertebral column (Wilson \& Carrano, 1999). In this way, the rebbachisaurid anterior caudal vertebrae show a marked reduction of the bony elements related to the intervertebral contact (zygapophyses), as well as the amphyplatian nature of their vertebral centra. On the other hand, these anterior caudal vertebrae show well-developed, wing-like transverse processes and tall neural spines (at least in Cathartesaura). All these features together suggest an important development of the musculature and elastic ligaments, related to the pelvic girdle, and to the mid and posterior caudal vertebrae respectively, the latter further evolving in relation to "whiplash" mechanics of flagellicaudate diplodocoids.

The diversity, biogeography and ecological importance of the Rebbachisauridae in the Late Cretaceous terrestrial ecosystems is still far from understood (Gallina et al., 2002). However, the discovery of a new rebbachisaurid taxon has broad implications in our comprehension of the sauropod evolution in the Cretaceous of Gondwana.

\section{ACKNOWLEDGEMENTS}

We thank the Avelás, Salinas and Pincheira families, C. Muñoz, L. Fernández, and the ENDEMAS and the Agencia Cultura of Río Negro for their valuable help in the field. Fieldwork and specimen preparation was possible thanks to J. A. and F. González, S. de Valais, A. Haro, A. M. Forasiepi, M. L. Balarino, F. L. Agnolín, M. Cárdenas, A. P. Carignano, A. Haluza, L. Gaetano, S. Reuil, and A. Scanferla. H. Leanza, H. Corbella, and R. R. Andreis are thanked for their geological advice. Fieldwork and study were generously supported by two projects to Fernando E. Novas, granted by The National Geographic Society and the Agencia Nacional de Promoción Científica y
Tecnológica. The Jurassic Foundation and The Rotary Club granted S.A. projects. L. Salgado, J. Wilson, José F. Bonaparte and an anonymous reviewer substantially improved this work with useful comments and/or critical review. P. Makovicky improved the English version of the original manuscript. Juan Canale, "Juje" Haluza, Pablo Chiarelli and Federico Agnolín offered rich discussions, and Jorge A. González made skillful drawings.

\section{BIBLIOGRAPHY}

Apesteguía, S. 2002. Successional structure in continental tetrapod faunas from Argentina along the Cretaceous. Boletim do $6^{\circ}$ Simpósio sobre o Cretáceo do Brasil - $2^{\circ}$ Simposio sobre el Cretácico de América del Sur. (Sao Pedro, Brasil), Abstracts, pp. 135-141.

- 2004. Bonitasaura salgadoi: A beaked sauropod in the Late Cretaceous of Gondwana. Naturwissenschaften 91(10): 493-497.

Apesteguía, S., S. de Valais, J. A. González, P. A. Gallina \& F. L. Agnolin. 2001. The tetrapod fauna of 'La Buitrera', new locality from the basal Late Cretaceous of North Patagonia, Argentina. Journal of Vertebrate Palaeontology 21, Abstracts, p. 29A.

Bonaparte, J. F. 1996. Cretaceous Tetrapods of Argentina. In Contributions of southern South America to Vertebrate Paleontology (eds. Pfeil, F. \& Arratia, G.). Münchner Geowissenschaftliche Abhandlungen. Reihe A. Geologie und Paläontologie 30: 73-130.

- 1997. Rayososaurus agrioensis Bonaparte 1995. Ameghiniana 34:116.

- 1999. Evolución de las vertebras presacras en Sauropodomorpha. Ameghiniana 30: 271-282

Casanovas, M. L., J. V. Santafé \& J. L. Sanz. 2001. Losillasaurus giganteus, un nuevo sauropodo del tránsito Jurásico-Cretácico de la cuenca de "Los Serranos" (Valencia, España). Paleontología i Evolució 32-33: 99-122.

Calvo, J. O. 1999. Dinosaurs and other vertebrates of the Lake Ezequiel Ramos Mexía area, Neuquén-Patagonia, Argentina. In 2nd Gondwanan Dinosaur Symposium (eds. Y. Tomida, T. H. Rich \& P. Vickers-Rich), Proceedings. National Science Museum Monographs (Tokyo) 15: 13-45.

Calvo, J. O. \& L. Salgado. 1995. Rebbachisaurus tessonei sp. nov. A new Sauropoda from the Albian-Cenomanian of Argentina; new evidence on the origin of the Diplodocidae. Gaia 11: 13-33.

- 1996. A land bridge connection between South America and Africa during Albian-Ceno- 
manian times based on sauropod dinosaur evidence. $39^{\circ}$ Congresso Brasileiro de Geología, Anais 7: 392-393.

- 1998. Nuevos restos de Titanosauridae (Sauropoda) en el Cretácico inferior de Neuquén, Argentina. 7th Congreso Argentino de Paleontología y Bioestratigrafía (Bahía Blanca), Abstracts, p. 59. [Unpublished].

Carvalho, I. S., L. dos Santos Avilla \& L. Salgado. 2003. Amazonsaurus maranhensis gen. et sp. nov. (Sauropoda, Diplodocoidea) from the Lower Cretaceous (Aptian-Albian) of Brazil. Cretaceous Research 24: 697-713.

Coria, R. A. \& L. M. Chiappe. 2001. Tooth replacement in a sauropod maxilla from the Upper Cretaceous of Patagonia, Argentina. Ameghiniana 38: 463-466.

Cope, E. D. 1877. On a gigantic saurian from the Dakota epoch of Colorado. Paleontological Bulletin 25: 5-10.

Corbella, H., F. E. Novas, S. Apesteguía \& H. A. Leanza. 2004. First fission-track age for the dinosaur-bearing Neuquén Group (Upper Cretaceous), Neuquén Basin, Argentina. Revista del Museo Argentino de Ciencias Naturales, nueva serie 6(2): 227-232.

Dalla Vecchia, F. M. Remains of Sauropoda (Reptilia, Saurischia) in the Lower Cretaceous (Upper Hauterivian/Lower Barremian) Limestones of SW Istria (Croatia). Geologia Croatica 51(2): 105-134.

Gallina, P. A., S. Apesteguía \& F. E. Novas. 2002. ¿Un elefante bajo la alfombra? Los Rebbachisauridae (Sauropoda, Diplodocimorpha) del Cretácico de Gondwana. Nuevas eviden-cias en "La Buitrera" (Fm. Candeleros), provincia de Río Negro. Ameghiniana 39 Supl. P. 10R.

Goloboff, P. 1993. Nona, computer program and software. Published by the author, Tucumán, Argentina.

Harris, J. D. \& P. Dodson. 2004. A new diplodocoid sauropod dinosaur from the Upper Jurassic Morrison Formation of Montana, USA. Acta Palaeontologica Polonica 49 (2): 197-210.

Hatcher, J. B. 1901. Diplodocus (Marsh): Its osteology, taxonomy, and probable habits, with a restoration of the skeleton. Memoirs of the Carnegie Museum 1: 1-63.

- 1903. Osteology of Haplocanthosaurus, with description of new species and remarks on probable habits of the sauropoda, and the age and origin of the Atlantosaurus beds. Memoirs of the Carnegie Museum 2: 1-72.

Huene, F. von. 1929. Los saurisquios y ornitisquios del Cretáceo Argentino. Anales del Museo de La Plata (Serie 2) 3: 1-196.

Jacobs, L., D. A. Winkler, W. R. Downs \& E. M.
Gomani. 1993. New material of an Early Cretaceous titanosaurid sauropod dinosaur from Malawi. Palaeontology 36: 523-534

Janensch, W. 1914. Übersicht über die Wirbeltierfauna der Tendaguru-Schichten, nebst einer kurzen Charakterisierung der neu aufgefuhrten Arten von Sauropoden. Arch. Biontol. 3: 81-110.

Lamanna, M. C., R. D. Martinez, M. Luna, G. Casal, P. Dodson \& J. Smith. 2001. Sauropod faunal transition through the Cretaceous Chubut group of Central Patagonia. Journal of Vertebrate Palaeontology 21, Abstracts p. $70 \mathrm{~A}$.

Lavocat, R. 1954. Sur les Dinosauriens du continental intercalaire des Kem Kem de la Daoura. Comptes Rendus 19th Session Congrès Géologique International. 1952, 3: 6568.

Leanza, H. A., S. Apesteguía, F. E. Novas \& M. de la Fuente. 2004. Cretaceous terrestrial beds from the Neuquén Basin (Argentina) and their tetrapod assemblages. Cretaceous Research 25: 61-87.

Leanza, H. A. \& C. A. Hugo. 2001. Cretaceous red beds from southern Neuquén Basin (Argentina): age, distribution and stratigraphic discontinuities. VIIo International Symposium on Mesozoic Terrestrial Ecosystems. Asociación Paleontológica Argentina, Publicación Especial 7: 111-122.

Linnaeus, C. v. 1758. Systema naturæ per regna tri naturæ, secundum classes, ordines, genera, species, cum characteribus, differentiis, synonymis, locis. Tenth ed. Laurentii Salvii, Stockholm, Sweden, 1: 1-824.

Marsh, O. C. 1877. Notice of a new gigantic dinosaur. American Journal of Science (Series 3) 14: 87-88.

- 1890. Description of new dinosaurian reptiles. American Journal of Science (Series 3) 39: 8186.

McIntosh, J. S. \& M. E. Williams. 1988. A new species of sauropod dinosaur, Haplocanthosaurus delfsi sp. nov., from the upper Jurassic Morrison Fm. of Colorado. Kirtlandia 43: 3-26.

Nopcsa, F. 1902. Notizen über die Cretacischen Dinosaurier. Pt. 3. Wirbel eines sudamerikanischen Sauropoden. Sitzber Berliner Akademie der Wesenschaften, Bd. 3: 108-114.

Pereda Suberbiola, X., F. Torcida Fernandez Baldor, M. Meijide Calvo, C. Fuentes Vidarte, L. A. Izquierdo, D. Montero \& G. Pérez. 2001. Un saurópodo rebaquisáurido (Dinosauria, Diplodocoidea) en el Cretácico inferior de Burgos, España. II Jornadas Internacionales 
sobre Paleontología de Dinosaurios y su entorno. España, 2001. Resúmenes.

Pereda Suberbiola, X., F. Torcida, L. A. Izquierdo, P. Huerta, D. Montero \& G. Perez. 2003. First rebbachisaurid dinosaur (Sauropoda, Diplodocoidea) from the Early Cretaceous of Spain: palaeobiogeographical implications: Bulletin de la Societé géologique de la France, t. 174, 5: 471-479.

Rauhut, O. W. M. 2002. Los dinosaurios de la Formación Cañadón Asfalto: diversidad, filogenia y biogeografía. XVIII ${ }^{o}$ Jornadas Argentinas de Paleontología de Vertebrados (Bahía Blanca). Ameghiniana 39 (Supplement), Abstracts, p. 15R.

Salgado, L. 2001. Los Saurópodos de Patagonia: sistemática, evolución y paleobiología. II Jornadas Internacionales sobre Paleontología de Dinosaurios y su entorno. Abstracts 139:168.

Salgado, L. \& J. F. Bonaparte. 1991. Un nuevo saurópodo Dicraeosauridae, Amargasaurus cazaui gen. et sp. nov. de la Formación La Amarga, Neocomiano de la Provincia del Neuquén, Argentina. Ameghiniana 28: 333346.

Salgado, L. \& J. O. Calvo. 1997. Evolution of titanosaurid sauropods II: The cranial evidence. Ameghiniana 34: 33-47.

Salgado, L., J. O. Calvo \& R. A. Coria. 1991. Un dinosaurio saurópodo de caudales anfipláticas del Cretácico de la Provincia de Neuquén. VIII ${ }^{\circ}$ Jornadas Argentinas de Paleontología de Vertebrados (La Rioja). Ameghiniana 28 (4), Abstracts, p. 412.

Salgado, L., R. A. Coria \& J. O. Calvo. 1997. Evolution of Titanosaurid Sauropods. I: phylogenetic analysis based on the postcranial evidence. Ameghiniana 34: 3-32.

Salgado, L., A. Garrido, S. E. Cocca \& J. R. Cocca. 2004. Lower Cretaceous Rebbachisaurid Sauropods From Cerro Aguada del León (Lohan Cura Formation), Neuquén Province, northwestern Patagonia, Argentina. Journal of Vertebrate Paleontology 24(4): 903-912.

Scotese, C. R. 2004. A continental drift flipbook. Journal of Geology 112:729-741.

Scotese, C. R., A.J. Boucot \& W.S. McKerrow. 1999. Gondwanan palaeogeography and palaeocli-matology. Journal of African Earth Sciences 28: 99-114.

Sereno, P. C., A. L. Beck, D. B. Dutheil, H. C. E. Larsson, G. H. Lyon, B. Moussa, R. W. Sadleir,
C. A. Sidor, D. J. Varricchio, G. P. Wilson \& J. A. Wilson. 1999. Cretaceous Sauropods from the Sahara and the uneven rate of skeletal evolution among dinosaurs. Science 286: 1342-1347.

Upchurch, P. 1999. The phylogenetic relationships of the Nemegtosauridae (Saurischia, Sauropoda). Journal of Vertebrate Paleontology 19: 106-125

Upchurch, P., P. M. Barret \& P. Dodson. 2004. Sauropoda. In Weishampel, D.B., Dodson, P. \& Osmólska, H. (eds) The Dinosauria, $2^{\text {nd }}$ ed. University of California Press, Berkeley.

Vrielynch, B. \& P. Bouysse. 2003. The changing face of the Earth: the break-up of pangea and continental drift over the past 250 million years in ten steps. Commision for the geological map of the world. 32pp+ 1 CD Unesco publishing.

Wedel, M. J. 2003a. The evolution of vertebral pneumaticity in sauropod dinosaurs. Journal of Vertebrate Paleontology 23(2): 344-357. 2003b. Vertebral pneumaticity, air sacs, and the physiology of sauropod dinosaurs. Paleobiology 29(2): 243-255.

Wedel, M. J., R. L. Cifelli \& R. K. Sanders. 2000. Osteology, paleobiology, and relationship of the sauropod dinosaurs Sauroposeidon. Acta Paleontologica Polonica 45: 343-388.

Wedel, M. J. \& K. Sanders. 2002. Osteological correlates of cervical musculature in Aves and Sauropoda (Dinosauria: Saurischia), with comments on the cervical ribs of Apatosaurus. PaleoBios 22 (3): 1-6.

Wilson, J. A. 1999. Evolution and phylogeny of sauropod dinosaurs. Unpublished PhD Dissertation, University of Chicago.

- 2002. Sauropod dinosaur phylogeny: critique and cladistic analysis. Zool J Linn Soc 136: 217-276.

- in press. Overview of sauropod phylogeny and evolution. In Curry Rogers, K. A. \& Wilson, J.A. (eds) Sauropod Paleobiology. University of California Press, Berkeley.

Wilson, J. A. \& M. T. Carrano. 1999. Titanosaurs and the origin of "wide-gauge" trackways: a biomechanical and systematic perspective on sauropod locomotion. Paleobiology 25(2): 252-267.

Wilson, J. A. \& P. C. Sereno. 1998. Early evolution and higher-level phylogeny of sauropod dinosaurs. Society of Vertebrate Paleontology, Memoir 5: 1-68. 


\section{APPENDIX I}

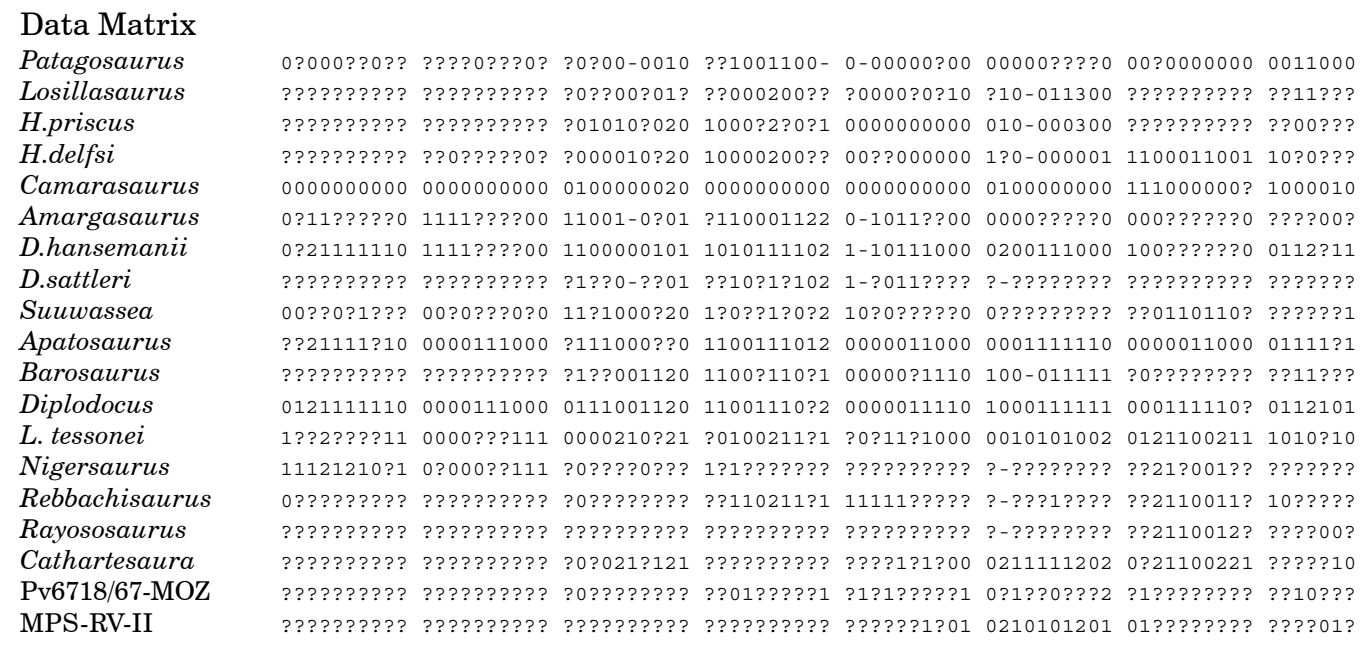

\section{APPENDIX II}

\section{List of Characters}

1. Longitudinal grooves on lingual aspect of teeth. Wilson, 2002 (76): 0. absent; 1. present (weakly developed).

2. Number of replacement teeth per alveolus. Wilson, 2002 (74): 0 . two or fewer; 1 . more than four.

3. Occlusal pattern. Wilson, 2002 (68): 0. interlocking, V-shaped facets; 1. high-angled planar facets; 2 . low angled planar facets.

4. Tooth shape: 0 . broad-crowned teeth; 1 . slender cylindrical pencil-like teeth at about $10 \mathrm{~mm}$ in diameter; 2 . slender compressed wire-like teeth at about $5 \mathrm{~mm}$ in diameter.

5. Shape of anterior portion of tooth row. Modified from Wilson, 2002 (65): 0. V-shaped or U-shaped; 1. rectangular, tooth-bearing portion of jaw perpendicular to jaw rami.

6. Tooth row length. Modified from Wilson, 2002 (66): 0. extending to subnarial foramen; 1. restricted anterior to subnarial foramen; 2 . restricted anterior and laterally extended beyond the rami level.

7. Shape of the premaxillary anterior margin. Modified from Wilson, 2002 (2): 0. with marked step, skull sharply demarcated; 1 . without step.

8. Shape of the anteroventral margin of the dentary. Wilson, 2002 (56): 0. gently rounded; 1 . sharply projecting triangular process or "chin".

9. Parietal contribution to post-temporal fenestra. Wilson, 2002 (22): 0. present; 1. absent.

10. Anteroposterior length of frontal. Modified from Wilson, 2002 (20): 0. less than the minimum transverse breadth; 1 . approximately twice the minimum transverse breadth.

11. Midline contact of frontals. Wilson, 2002 (19): 0. sutured; 1 . fused in adult individuals.

12. Angle of divergence of the basipterygoid processes. Wilson, 2002 (47): 0 . approximately $45^{\circ} ; 1$. less than $30^{\circ}$.

13. Breadth of the basal tubera. Wilson, 2002 (49): 0 . much broader than occipital condyle; 1 . narrower than occipital condyle.

14. Size of the crista prootica. Wilson, 2002 (45): 0. rudimentary; 1. expanded laterally into dorsolateral processes.

15. Position of the external nares in dorsal view. Modified from Wilson, 2002 (8): 0. retracted to level of orbits; 1. retracted to a position between the orbits.

16. Maximum diameter of the antorbital fenestra. Wilson, 2002 (6): 0 . much shorter than orbital maximum diameter; 1 . subequal to orbital maximum diameter.

17. Contribution to antorbital fenestra of jugal. Wilson, 2002 (13): 0 . very reduced or absent; 1 . large, bordering approximately one-third its perimeter.

18. Anteroposterior length of ventral margin of the orbit. Modified from Wilson, 2002 (10): 0. reduced, with acute orbital margin; 1 . broad, with subcircular orbital margin.

19. Posterior process of postorbital. Wilson, 2002 (17): 0. present; 1 . absent.

20. Supratemporal fenestra. Wilson, 2002 (25): 0. present; 1. absent.

21. Postparietal foramen. Wilson, 2002 (23): 0. absent; 1. present.

22. Shape of the presacral neural spines. Modified from Wilson, 2002 (89): 0. single; 1. bifid. 
23. Number of cervical vertebrae. Modified from Wilson, 2002 (80): 0.13 or fewer; 1.15 or greater.

24. Shape of the centroprezygapophyseal lamina (cprl) in middle and posterior cervical vertebrae. Wilson, 2002 (88): 0. single; 1 . divided.

25. Accessory lateral lamina connecting postzygodiapophyseal and spinoprezygapophyseal laminae in posterior cervical vertebrae: 0 . absent; 1 . poorly developed; 2 . present and well developed.

26. pneumatization of posterior cervical centra: 0 . extended to the anterior half of the centrum; 1 . extended to the posterior half of the centrum.

27. Anteroposterior length/height of the posterior face, in mid-cervical centra. Wilson, 2002 (86): 0. 2.5-3.0; $1 .>4$.

28. Ventral surface of each cervical centrum. Casanovas et al., 2001 (4): 0. flat or lightly convex transversely; 1. transversely concave.

29. Lateral surfaces of the cervical centra. Casanovas et al., 2001 (7): 0. lacking lateral excavations or with only very weak depressions; 1 . deeply excavated but without an oblique accessory lamina; 2 . possessing a deep excavation that is divided into cranial and caudal portions by oblique accessory lamina.

30. Cervical neural spine. Casanovas et al., 2001 (10): 0. low (the height of the vertebra does not exceed the length of the centrum); 1 . high (the height of the vertebra is at least 1.5 times the lenght of the centrum).

31. Length of the cervical ribs. Wilson, 2002 (140): 0. much longer than centrum, overlapping as many as three subsequent vertebrae; 1 . shorter than centrum, little or no overlap.

32. Number of dorsal vertebrae. Modified from Wilson, 2002 (91): 0.11 or greater; 1.10 or fewer.

33. Dorsal pleurocoels. Modified from Wilson, 2002 (78): 0. present; 1. absent.

34. Hyposphene-hypantrum articulation in dorsal vertebrae. Wilson, 2002 (106): 0. present; 1. absent.

35. Shape of the centropostzygapophyseal lamina (cpol), in middle and posterior dorsal vertebrae. Wilson, 2002 (95): 0. single; 1 . divided.

36. Height of the neural arch pillars until the prezygapophyses in respect to the centrum height in middle and posterior dorsal vertebrae: 0 . low, lesser than the centrum height; 1 . mid-sized, about the centrum height; 2 . tall, at least 1.5 times the centrum height.

37. Shape of middle and posterior dorsal neural spines. Modified from Wilson, 2002 (102): 0. flared distally, with pendant , triangular lateral processes; 1 . tapering or not flaring distally.

38. Length of dorsal neural spines. Wilson, 2002 (93): 0. approximately twice centrum length; 1 . approximately four times centrum length.

39. Orientation of the tuberculum in mid dorsal ribs: 0 . spreading outside from rib shaft; 1 . following straight direction of rib shaft; 2 . following medial bent of rib shaft.

40. Anterior axial lamina (sprl+prsl) in posterior dorsal vertebrae. Modified from Salgado et al., 2004 (34): 0. absent, there are two independent and non-coalescent anterior laminae; 1 . incompletely fused, both laminae are individualized but form a double central structure; 2 . present, the prespinal laminae is single and well developed.

41. Well developed deep triangular cavity formed between centrodiapophyseal, centroprezygapophyseal and prezygodiapophyseal laminae in posterior dorsal vertebrae: 0 . absent; 1 . present.

42. Pleurocoel size on posterior dorsal vertebrae: 0 . small, occupying about one quarter to one third of the centrum; 1. large, occupying almost all the upper half of the centrum.

43. Spinopostzygapophyseal laminae join the postspinal lamina over the diapophysis origin level in dorsal vertebrae: 0 . absent; 1 . present.

44. Medial spinopostzygapophyseal lamina (sensu Salgado et al., 2004) in posterior dorsal vertebrae: 0. absent; 1. present.

45. Shape of posterior dorsal and anterior caudal neural spines. Modified from Wilson, 2002 (107): 0. rectangular through most of length; 1 . "petal" shaped, expanding transversely through $75 \%$ of its length and then tapering.

46. Length of the sacral neural spines. Wilson, 2002 (111): 0. approximately twice length of the centrum; 1 . or four times length of centrum.

47. "Dorsalization" of the neural spines of the proximal caudals. Casanovas et al., 2001 (35): 0. absent (spines ar simple, laterally compressed, and lack laminae); 1 . present (spines very similar to those of the dorsal vertebrae).

48. Length of anterior caudal centra. Wilson, 2002 (120): 0. approximately the same over the first 20 vertebrae; 1. or doubling over the first 20 vertebrae.

49. Shape of the articular face of anterior caudal vertebrae. Modified from Wilson, 2002 (118): 0. flat; 1. procoelus.

50. Shape of the posterior articular face of anterior caudal vertebrae: 0 . less or equal to the anterior articular face; 1 . more concave than the anterior articular face (i.e. slightly opisthocoelous).

51. Pneumatopores in anterior caudal centra. Wilson, 2002 (119): 0. absent; 1. present.

52. Lateral shape of the anterior caudal neural spine: 0 . straight; 1 . scimitar-shaped; 2 . S-shaped.

53. Lateral lamina of the neural spine on anterior caudal vertebrae showing thick external borders: 0 . absent; 1 . present.

54. Prespinal lamina of the neural spine on anterior caudal vertebrae with a thickened anterior rim: 0 . absent; 1. present.

55. Height of the anterior caudal vertebrae spine: 0 . low, subequal to the centrum height; 1 . tall, more than 2 times the centrum height. 
56. Shape of the anterior caudal transverse processes. Wilson, 2002 (128): 0. triangular distally; 1. "wing-like”, not tapering distally.

57. Relative development of the ventral and dorsal components of the anterior caudal transverse processes. Salgado et al., 2004 (42): 0. dorsal component poor; 1. well developed.

58. Components of the lateral marginal lamina in anterior caudal vertebrae neural spine. Modified from Wilson, 2002 (122): 0. only spinoprezygapophyseal. No contact with lateral postzygapophyseal lamina; 1. spinoprezygapophyseal lamina (sprl) + lateral spinopostzygapophyseal lamina (lat. spol) contact in anterior caudal vertebrae; 2 . lat. spol is the main component of the lateral border of the neural spine; 3 . the lateral lamina of the neural spine in caudal vertebrae is not formed by neither sprl or lat. spol.

59. Shape of the anterior centrodiapophyseal lamina (acdl), in anterior caudal vertebrae. Wilson, 2002 (130): 0. single; 1 . divided.

60. Shape of the mid caudal centra. Modified from Wilson, 2002 (131): 0. cylindrical; 1. quadrangular, flat ventrally and laterally; 2. triangle-shaped (wide base).

61. Orientation of prezygapophysis in mid caudal vertebrae: 0 . horizontal; 1 . upward.

62. Chevrons, "crus" bridging dorsal margin of haemal canal. Wilson, 2002 (145): 0. present; 1. absent.

63. Shape of the scapular blade. Wilson, 2002 (152): 0. acromial edge (or posterior process) not expanded; 1. rounded expansion; 2 . racquet-shaped.

64. Acromion dorsal margin of the scapula: 0. curved; 1 . straight.

65. Posterior acromial axis of the scapula: 0 . subvertical to the scapular diaphysis axis; 1 . oblique to the scapular diaphysis axis.

66. Scapular process located along the ventral margin at the level of the acromion origin: 0 . absent; 1 . present.

67. Scapular-coracoid articulation: 0 . subvertical in respect to long axis of the scapula; 1 . oblique.

68. Acromion length: $0.1 / 3$ or less the scapular length; 1 . $1 / 2$ to $1 / 3$ scapular length; 2 . approximately $1 / 2$ scapular length.

69. Hook-like acromion process: 0 . absent; 1 . present; 2 . extended as a finger..

70. Direction of the pubic peduncle relative to the ilium shaft: 0 . oblique, and the ilium axis is horizontal; 1 . straight, and the ilium axis is oblique.

71. Shape of ischial shaft. Wilson, 2002 (195): 0 . V shaped, nearly $50^{\circ}$; 1 . flat, nearly coplanar.

72. Shape of ischial distal shaft. Modified from Wilson, 2002 (194): 0. medial and lateral depths subequal; 1. depth of ischial shaft increase medially.

73. Relative length of iliac articular surface of pubis. Salgado et al., 2004 (49): 0. shorter than the acetabular portion of the pubis; 1 . longer than the acetabular portion of the pubis.

74. Development of ambiens process of pubis. Modified from Wilson, 2002 (189): 0. small, confluent, not differentiated from the anterior border of the pubis; 1 . evident, but not especially developed; 2 . prominent, projecting anteriorly from anterior margin of pubis.

75. Posterior development of femoral tibial condyle in respect to the fibular condyle: 0 . well developed; 1 . poorly developed.

76. Position of 4 th trochanter in anterior view: 0 . not visible (located on the posterior side); 1 . visible (located toward the medial side).

77. Posterolateral projection of metatarsal I distal condyle. Wilson, 2002 (220): 0. absent; 1. present. 